\title{
PERSPEKTIF ILMU EKONOMI DAN UNDANG-UNDANG NOMOR 5 TAHUN 1999 TENTANG LARANGAN PRAKTIK MONOPOLI DAN PERSAINGAN USAHA TIDAK SEHAT TERHADAP DISKRIMINASI HARGA
}

\author{
Irwan Sugiarto \\ Dosen Tetap Sekolah Tinggi Hukum Bandung \\ E-mail: irwan.sugiarto@yahoo.com
}

\begin{abstract}
Unfair business competition can cause and trigger monopoly practice where markets are controlled and dominated by business doers. Besides, another impact of monopoly practice is that; the business doers tend to sell expensive products without good quality. Monopoly business doers often apply price strategy where the entrepeneurs at normal competitive markets are not possible to do that. One of price strategies is price discrimination. Price discrimination refers to different price determination at a product at different time to every differentcustomer, or differentmarket, but it is not based on different cost. Price discrimination can be distinguished into three kinds, namely first degree price discrimination, second degree price discrimination, and third degree price discrimination. In addition to that, there is a variant in second degree price discrimination and third degree price discrimination, namely two part tariff, intertemporal price discrimination, and also peak load pricing.

In Act No. 5 year 1999, discrimination related to prices is regulated in two groups of rules and articles, that is to say price discrimination which is aproved under agreement, and discrimination which is performed by unilateral agreement or without agreement.
\end{abstract}

Keywords: economy; price discrimination; monopoly; business competition.

\begin{abstract}
Abstrak
Persaingan usaha yang tidak sehat dapat menyebabkan timbulnya praktik monopoli di mana pasar hanya dikuasai oleh pelaku usaha tersebut. Selain itu akibat lain yang timbul adalah kecenderungan pelaku usaha menjual barang yang mahal tanpa kualitas yang memadai. Pengusaha monopoli seringkali menerapkan strategi harga yang tidak mungkin dilakukan oleh para pengusaha yang berada pada pasar persaingan sempurna. Salah satu contoh strategi tersebut adalah diskriminasi harga (price discrimination). Diskriminasi harga (price discrimination) mengacu pada penentuan harga yang berbeda pada sebuah produk, pada waktu yang berbeda untuk setiap pelanggan yang berbeda, atau pasar yang berbeda, tetapi bukan berdasarkan perbedaan biaya. Diskriminasi harga dapat dibedakan menjadi tiga jenis, yaitu diskriminasi harga derajat pertama, derajat kedua, dan derajat ketiga. Selain itu terdapat varian dari diskriminasi harga derajat kedua dan derajat ketiga, yaitu two part tariff, intertemporal price discrimination dan peak load pricing.

Di dalam Undang-Undang Nomor 5 Tahun 1999, diskriminasi yang berkaitan dengan harga diatur dalam dua kelompok aturan atau pasal, yakni diskriminasi harga yang disepakati di bawah payung perjanjian dan diskriminasi yang dilakukan secara sepihak atau tanpa perjanjian.
\end{abstract}

Kata kunci: Ekonomi, Diskriminasi Harga, Monopoli, Persaingan Usaha. 


\section{A. PENDAHULUAN}

Kegiatan ekonomi merupakan aktivitas yang tidak dapat dilepaskan dari kehidupan manusia, bahkan kegiatan ekonomi telah ada sejak manusia mengenal kebudayaan. Kegiatan ekonomi merupakan salah satu pilar penting dalam dinamika kehidupan manusia, karena manusia selalu mempunyai kebutuhan hidup baik primer, sekunder maupun tertier, sehingga semakin komplek kebutuhan manusia akan semakin meningkat pula kegiatan ekonominya. Pada era globalisasi dan perdagangan bebas seperti sekarang ini, kegiatan ekonomi menjadi semakin intens dan luas menjangkau seluruh bagian dunia dan mempunyai cakupan seluas kegiatan manusia di mana saja berada, jarak dan waktu bukanlah merupakan penghalang lagi bagi kegiatan ekonomi. Kegiatan ekonomi pada dasarnya merupakan satu rangkaian kegiatan yang bersifat simultan, komprehensif, dan terus menerus.

Pihak yang menjalankan kegiatan ekonomi disebut pelaku ekonomi, baik peroranganmaupunyangbersifatkelompok atau badan usaha. Dalam menjalankan kegiatan ekonominya tersebut, para pelaku usaha akan menghadapi persaingan, dan itu merupakan persyaratan bagi terselenggaranya ekonomi pasar, terlebih lagi dalam era global yang menuntut sistem ekonomi pasar bebas, sehingga persaingan antar pelaku usaha akan lebih terbuka. Adakalanya persaingan usaha tersebut merupakan persaingan yang sehat (fair competition), namun dapat juga terjadi persaingan tidak sehat (unfair competition) untuk mendapatkan keuntungan yang sebesar-besarnya.

Teori ekonomi pasar bebas yang diperkenalkan Adam Smith dikenal sebagai persaingan sempurna. Dalam pasar sempurna, terdapat banyak perusahaan yang beroperasi untuk menjual barang dengan karakteristik yang serupa. Kemampuan mereka untuk mengatur harga pasar ditentukan oleh mekanisme penawaran (supply) dan permintaan (demand) sendiri yang bisa dicapai oleh pasar (price equilibrium), maksudnya ketika pelaku usaha menaikkan harga, maka kemungkinan mereka akan kehilangan sejumlah pembeli yang mencari perusahaan atau penjual yang menjual dengan harga murah. ${ }^{1}$

Dalam dunia usaha, persaingan harus dipandang sebagai hal yang positif. Dalam Ilmu Ekonomi, persaingan yang sempurna adalah suatu kondisi pasar yang ideal. Paling tidak ada empat asumsi yang melandasi agar terjadinya persaingan yang sempurna pada suatu pasar tertentu:

Pertama, pelaku usaha tidak dapat menentukan secara sepihak harga atas produk atau jasa. Adapun yang menentukan harga adalah pasar berdasarkan equilibrium permintaan dan penawaran. Kedua, barang dan jasa yang dihasilkan oleh pelaku usaha mempunyai kebebasan untuk masuk ataupun keluar dari pasar "perfect homogeneity", Ketiga, pelaku usaha mempunyai kebebasan untuk masuk ataupun keluar dari pasar "perfect mobility of resource", dan Keempat, konsumen dan pelaku pasar memiliki

1 D. Carlton dan J. Perloff, Modern Industrial Organization, Addiso-Wesley Longman Inc, New York, 1999, hlm. 68. 
informasi yang sempurna tentang berbagai hal. ${ }^{2}$

Walaupun dalam kehidupan nyata sukar ditemui pasar yang didasarkan pada mekanisme persaingan yang sempurna, namun persaingan dianggap sebagai suatu hal yang esensial dalam ekonomi pasar. Persaingan usaha atau kompetensi antar para pelaku usaha dalam merebut pasar adalah hal yang sangat wajar. Namun hal itu menjadi tidak wajar manakala persaingan tersebut dilakukan dengan cara yang curang (unfair), dengan tujuan untuk menghalangi pelaku usaha lain untuk bersaing (barrier to entry) atau mematikan usaha persainganya. Namun demikian, kompetisi dapat dilaksanakan secara wajar, apabila tercipta pertumbuhan dunia usaha yang sehat dan menjamin adanya kesempatan berusaha yang sama. Untuk itu dibutuhkan suatu iklim persaingan usaha yang kondusif.

Persaingan usaha yang tidak sehat dapat menyebabkan timbulnya praktik monopoli di mana pasar hanya dikuasai oleh pelaku usaha tersebut. Selain ituakibat lain yang timbul adalah kecenderungan pelaku usaha menjual barang yang mahal tanpa kualitas yang memadai. ${ }^{3}$ Pengusaha monopoli seringkali menerapkan strategi harga yang tidak mungkin dilakukan oleh para pengusaha yang berada pada pasar persaingan sempurna. Salah satu contoh strategi tersebutadalah diskriminasi harga (price discrimination). Dengan kebijakan diskriminasi harga, maka terhadap komoditas yang sama akan dikenakan harga yang berbeda. Dalam hal ini variasi harga dapat terjadi untuk pembeli yang sama, untuk pembeli yang berbeda, atau untuk pembeli yang sama dan berbeda. Dalam melakukan diskriminasi harga, perbedaan bukan didasarkan pada perbedaan dalam biaya produksi. ${ }^{4}$

Diskriminasi harga perlu dibedakan dengan perbedaan harga. Perbedaan harga (price differential) bukanlah suatu diskriminasi harga, melainkan harga yang berbeda dikenakan kepada konsumenyang berlainan. Misal, sebuah pabrik di Jakarta menjual radio di Jakarta dengan harga Rp. 100.000,00 dan menjual barang yang sama ke Bandung dengan harga Rp. 125.000,00. Bila perbedaan Rp. 25.000,00 per radio tersebut disebabkan oleh perbedaan biaya transportasi, maka hal tersebut bukanlah kasus diskriminasi harga.

Perusahaan yang memiliki kemampuan monopoli memiliki rangsangan menerapkan diskriminasi harga karena kebijakan tersebut dapat meningkatkan keuntungan dengan pertimbangan tidak terlalu mahalnya biaya yang dikeluarkan untuk mengidentifikasi keinginan pembeli potensial yang berbeda-beda dan mencegah upaya penjualan ulang. Bila monopolis yang mampu mencapai monopoli alamiah bertujuan memaksimumkan keuntungan, maka tindakannya akan merugikan masyarakat, karena masyarakat hanya

2 Robert S Pindycle and Daniel L. Rubinfeld, Microeconomic, Prentice Hall International Inc, USA, 1998, hlm. 283-284.

3 Hikmahanto Juwana, "Sekilas Tentang Hukum Persaingan dan Undang-Undang Nomor 5 Tahun 1999”, Jurnal Magister Hukum, (September 1999), hlm. 32.

4 Sugiarto, et.al, Ekonomi Mikro Sebuah Kajian Komprehensif, PT. Gramedia Pustaka Utama, Jakarta, 2002, hlm. 381 . 
memperoleh sebagian saja komoditas yang dapat dihasilkan oleh perusahaan tersebut dengan harga yang relatif tinggi. Kerugian yang diderita masyarakat menjadi bertambah serius mengingat perusahaan monopoli alamiah pada umumnya menghasilkan komoditas yang sangat penting artinya bagi kehidupan masyarakat. Dengan demikian diperlukan campur tangan pemerintah untuk menjamin agar kegiatan perusahaan tersebut menguntungkan masyarakat. Bentuk campur tangan pemerintah tersebut biasanya berupa pengendalian dan penetapan harga komoditas yang dihasilkan oleh perusahaan monopoli yang umum dikenal dengan ceiling price. ${ }^{5}$

Dalam mengatur perekonomian, pemerintah dapat menggunakan wewenangnya untuk menentukan harga maksimum dari komoditas yang dihasilkan oleh seorang monopolis. Tindakan tersebut ditujukan untuk melindungi masyarakat dari penetapan harga yang terlalu tinggi dan jumlah komoditas yang terlalu sedikit. Meski demikian pada umumnya pemerintah juga menjaga agar kebijakannya tidak sampai terlalu merugikan produsen monopolis tersebut. Bila harga yang ditetapkan pemerintah terlalu rendah, maka pemerintah akan memberikan subsidi kepada perusahaan monopoli alamiah tersebut.

Bentuk lain campur tangan pemerintah, pemerintah Indonesia telah mengeluarkan Undang-Undang Nomor 5 Tahun 1999 tentang Lapangan Praktek Monopoli dan Persaingan Usaha Tidak Sehat (selanjutnya disebut UU No. 5 Tahun
1999) untuk menciptakan persaingan usaha yang sehat dengan terbangunnya iklim yang kondusif, agar tercipta pertumbuhan dunia usaha yang sehat dan menjamin adanya kesempatan berusaha yang sama.

UU Nomor 5 Tahun 1999 telah mengantisipasi beberapa perilaku pelaku usaha yang tidak sehat yang dilakukan oleh pelaku usaha dalam menciptakan kekuatan pasar yang cenderung anti persaingan. Salah satu bentuk tindakan yang anti persaingan adalah Diskriminasi Harga. Diskrimininasi Harga merupakan salah satu bentuk perjanjian yang dilarang oleh UU No. 5 Tahun 1999 yang dapat terjadi melalui penetapan harga berbeda yang dilakukan oleh pelaku usaha untuk barang dan atau jasa yang sama dari suatu produsen berdasarkan kriteria tertentu, atau mengenakan harga berbeda untuk pelanggan berbeda berdasarkan tambahan yang tidak proporsional di atas biaya marjinal atau dapat juga diartikan sebagai strategi penetapan harga non-linear yang mencoba untuk dapat memperoleh surplus konsumen lebih banyak.

Selain itu diskriminasi harga dapat terjadi apabila pelaku usaha menentukan harga sehingga perbedaan antara harga rata-rata dengan biaya rata-rata bervariasi diantara penjualan barang yang sama atau barang yang fungsinya hampir sama. Diskriminasi harga hanya dapat terjadi pada barang dan atau jasa yang sama dengan kuantitas yang sama. Semua pengertian di atas mengacu pada praktik diskriminasi harga berdasarkan daya beli atau pendapatan konsumen yang 
diproyeksikan dari struktur biaya pelaku usaha.

Berdasarkan latar belakang masalah di atas, permasalahan yang akan dibahas dalam makalah ini dibatasi dan diidentifikasi sebagai berikut:

1. Bagaimanakah perspektif ilmu ekonomi terhadap diskriminasi harga?

2. Bagaimanakah perspektif UndangUndang Nomor 5 Tahun 1999 tentang Larangan Praktik Monopoli dan Persaingan Usaha Tidak Sehat terhadap diskriminasi harga?

\section{B. PEMBAHASAN}

\section{Perspektif Ilmu Ekonomi Terhadap Diskriminasi Harga}

Diskriminasi harga (price discrimination) mengacu pada penentuan harga yang berbeda pada sebuah produk, pada waktu yang berbeda untuk setiap pelanggan yang berbeda, atau pasar yang berbeda, tetapi bukan berdasarkan perbedaan biaya. ${ }^{6}$ Sebagai contoh dari diskriminasi harga yaitu 1). Praktik penentuan harga oleh perusahaan energi (listrik dan gas); 2). Praktik penentuan harga oleh profesional dalam bidang kesehatan dan hukum, yang menentukan harga rendah untuk kelompok yang berpenghasilan rendah dan harga tinggi untuk yang berpenghasilan tinggi; 3). Penentuan harga yang lebih mahal di luar negeri dibanding di dalam negeri untuk berbagai produk dan jasa mulai dari buku, obat-obatan, dan film; 4). Penentuan harga yang lebih murah untuk pertunjukan siang hari dibanding malam hari, yaitu pada pertunjukan bioskop, teater, dan peristiwa olahraga; 5). Penentuan jasa potong rambut, angkutan umum, dan tiket pesawat yang lebih murah untuk anakanak dan usia lanjut; 6). Penentuan tarif menginap di hotel yang lebih murah untuk acara-acara rapat, dan sebagainya. Contohcontoh ini adalah indikasi tentang beberapa meluasnya penerapan diskriminasi harga dalam perekonomian Indonesia.

Namun demikian, harus diingat bahwa perbedaan harga akibat perbedaan biaya dalam memasok suatu produk atau jasa dengan jumlah yang berbeda, pada waktu yang berbeda, pada kelompok konsumen yang berbeda, atau dalam pasar yang berbeda, tidaklah termasuk dalam kelompok diskriminasi harga. Agar menjadi diskriminasi harga, perbedaan ini tidaklah boleh berdasarkan perbedaan dalam biaya. Juga perlu ditekankan bahwa diskriminasi harga tidak memiliki konotasi yang negatif dalam ilmu ekonomi (tidak seperti dalam ilmu hukum). Artinya, dalam ilmu ekonomi, diskriminasi harga bersifat netral dan menguntungkan sebagian orang (yang membayar harga yang lebih rendah bagi produk itu ketimbang jika tidak ada diskriminasi harga) dan juga merugikan sebagian lainnya, dan karena itu, seringkali sulit atau bahkan tidak mungkin untuk menentukan, apakah diskriminasi harga menguntungkan atau merugikan bagi masyarakat secara keseluruhan.

Tiga kondisi harus dipenuhi agar sebuah perusahaan dapat menerapkan diskriminasi harga, yaitu: ${ }^{7}$

\footnotetext{
6 Dominick Salvatore, Ekonomi Manajerial Dalam Perekonomian Global, Edisi 5, Buku 2, Salemba Empat, Jakarta, 2005, hlm. 129.

7 Ibid.
} 
a. Perusahaantersebutharus mempunyai kemampuan mengendalikan harga produk (artinya, perusahaan tersebut haruslah perusahaan persaingan tidak sempurna). Perusahaan persaingan sempurna tidak memiliki kendali atas harga produk yang dijual (artinya, dia bertindak sebagai price taker) dan dengan demikian tidak mungkin menerapkan diskriminasi harga.

b. Elastisitas harga permintaan terhadap produk tersebut harus berbeda untuk jumlah produk yang berbeda, pada waktu yang berbeda, untuk kelompok pelanggan yang berbeda, atau dalam pasar yang berbeda. Jika elastisitas permintaannya sama, maka perusahaan tersebut tidak dapat meningkatkan pendapatannya dan labanya dengan menerapkan diskriminasi harga.

c. Jumlahprodukataujasatersebut,kapan waktu digunakan atau dikonsumsinya produk tersebut, dan kelompok pelanggan atau pasar bagi produk tersebut harus dapat dipisahkan (artinya, perusahaan tersebut harus mampu melakukan segmentasi pasar). Jika tidak, individu atau perusahaan akan membeli produk atau jasa dari tempat murah dan menjualnya kembali di tempat yang harganya lebih mahal, sehingga menggagalkan upaya perusahaan untuk menerapkan harga yang berbeda bagi produk yang sama (yaitu menerapkan diskriminasi harga). Dalam kasus listrik, gas, air bersih, meteran yang dipasang di lokasi bisnis atau di rumah-rumah membuat pasar menjadi terpisahkan. Biaya transportasi dan pembatasan perdagangan memisahkan pasar komestik dan luar negeri. Dalam hal penjualan jasa, pasar secara alamiah bersifat terpisah oleh kenyataan bahwa kebanyakan jasa (misalnya, kunjungan dokter, konsultasi dokter, potong rambut, tiket angkutan umum untuk kelompok lanjut usia, dan lain-lain) tidak dapat dengan mudah dipindahkan atau dijual kembali kepada orang lain.

Menurut Sugiarto, et.al. ${ }^{8}$, diskriminasi harga dapat dibedakan menjadi tiga jenis, yaitu diskriminasi harga derajat pertama, derajat kedua, dan derajat ketiga. Selain itu terdapat varian dari diskriminasi harga derajat kedua dan derajat ketiga, yaitu two part tariff, intertemporal price discrimination dan peak load pricing.

\section{Diskriminasi Harga Derajat Pertama}

Dalam diskriminasi harga derajat pertama, monopolis berusaha sepenuhnya untuk mengambil seluruh surplus konsumen dengan cara menentukan harga yang berbeda untuk setiap jumlah komoditas yang berbeda. Dengan menggunakan kebijakan initiapunitoutput dijual pada tingkat harga maksimum yang mau dibeli oleh pembeli.

Penjelasan tentang diskriminasi harga akan dimulai dengan ilustrasi awal sebagai berikut: 
Monopolis menghasilkan suatu jurnal yang terbit bulanan. Terhadap jurnal tersebut tiap konsumen hanya akan membeli satu unit tiap bulannya; jarang diantara mereka mau membeli dua atau lebih jurnal yang sama bahkan dengan harga yang lebih rendahpun. Kurva permintaan yang dihadapi oleh pengusaha monopoli tersebut ditunjukkan oleh kurva D yang memiliki kemiringan negatif karena konsumen hanya mau membayar dengan harga yang berbeda untuk kuantitas yang berbeda (Gambar 1).

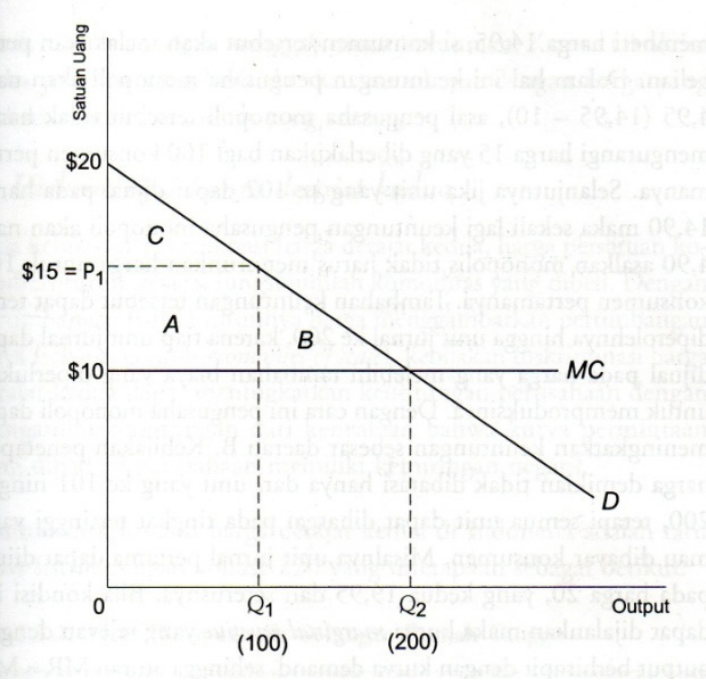

\section{Gambar 1}

\section{Diskriminasi Harga Derajat Pertama}

Pada tingkat harga yang paling rendah, kualitas jurnal yang diminta meningkat karena lebih banyak konsumen yang mau membeli jurnal tersebut. Tetapi tiap konsumen hanya membeli satu unit jurnal. Margin cost per jurnalnya konstan pada 10. Monopolis harus menetapkan harga yang sama untuk tiap konsumen, dengan memperhatikan pencapaian tingkat keuntungan maksimal, mereka akan menetapkan harga 15 pada unit output 100, sehingga keuntungan yang dapat diraihnya ditunjukkan oleh daerah A. Seandainya pengusaha monopolis tersebut berharap untuk meningkatkan keuntungannya atas dasar kurva permintaan yang dihadapinya, maka yang bersangkutan dapat menerapkan kebijakan diskriminasi harga. Katakan ada satu konsumen yang mau membeli jurnal tersebut pada harga yang lebih rendah dari 15, (misalkan 14,95) terhadap jurnal yang belum terjual, maka jika pengusaha monopoli dapat memberi harga 14,95, si konsumen tersebut akan melakukan pembelian. Dalam hal ini keuntungan pengusaha monopoli akan naik 4,95 (14,95-10), asal pengusaha monopoli tersebut tidak harus mengurangi harga 15 yang diberlakukan bagi 100 konsumen pertamanya. Selanjutnya jika unit yang ke102 dapat dijual pada harga 4,90 asalkan monopolis tidak harus menurunkan harga untuk 101 konsumen pertamanya. Tambahan keuntungan tersebut dapat terus diperolehnya hingga unit jurnal ke200, karena tiap unit jurnal dapat dijual pada harga yang melebihi tambahan biaya yang diperlukan untuk memproduknya. Dengan cara ini pengusaha monopoli dapat meningkatkan keuntungan sebesar daerah B. Kebijakan penetapan harga demikian tidak dibatasi hanya dari unit yang ke-101 hingga 200, tetapi semua unit dapat dihargai pada tingkat tertinggi yang mau dibayar konsumen. Misalnya unit jurnal pertama dapat dijual pada harga 20, yang kedua 19,95 dan seterusnya. Bila kondisi ini dapat dijalankan, maka kurva marginal revenue yang relevan dengan output berhimpit dengan kurva demand, sehingga aturan MR = MC untuk 
memperoleh keuntungan maksimal akan menghasilkan output sebesar Q2. Pada kondisi ini keuntungan monopolis ditunjukkan oleh daerah $\mathrm{A}+\mathrm{B}=\mathrm{C}$ yang bernilai lebih besar dibandingkan dengan bila hanya diterapkan harga tunggal 15 bagi semua unit.

Dalam kenyataannya untuk menerapkan kebijakan diskriminasi harga derajat pertama tidaklah mudah, dibutuhkan mekanisme sedemikian rupa agar monopolis dapat menerapkan harga maksimum yang mau dibayar oleh pembeli terhadap produk-produk yang dihasilkan oleh monopolis. Bertanya langsung pada pembeli tentang keinginan membayar mereka tentu bukan merupakan cara yang baik, upaya pencarian informasi dengan teknik-teknik tertentu seringkali dijalankan, misalnya pengacara dan dokter memberikan tarif yang berbeda kepada konsumen mereka yang kaya dan yang miskin seandainya mereka mengetahui kondisi ekonomi konsumennya. Para broker mobil bekas juga seringkali menerapkan kebijakan ini. Meski mereka tidak dapat secara sempurna memperkirakan harga tertinggi yang mau dibayar oleh konsumen, mereka seringkali menerapkan taktik kira-kira dengan menggali minat konsumen. Karena taktik ini, maka pembeli yang berbeda akan membayar dengan harga yang berbeda untuk komoditas yang berbeda.

\section{Diksriminasi Harga Derajat Kedua}

Pada kebijakan diskriminasi harga derajat kedua, harga persatuan komoditas turun sebagai fungsi jumlah komoditas yang dibeli. Dengan pertimbangan bahwa turunnya harga menggambarkan pertimbangan biaya (sebagai contoh economies of scale), kebijakan diskriminasi harga derajat kedua dapat meningkatkan keuntungan perusahaan dengan mengambil keuntungan dari kenyataan bahwa kurva permintaan yang dihadapi perusahaan memiliki kemiringan negatif.

Contoh diskriminasi harga derajat kedua di Indonesia adalah tarif dasar listrik dengan volume 220 yang ditetapkan sebagai berikut:

8 Sugiarto, et.al., Ekonomi Mikro..., Op.Cit., hlm. 384-392. 
Tabel 1

Tarif Tenaga Listrik untuk Keperluan Rumah Tangga ${ }^{9}$

\begin{tabular}{|c|c|c|c|c|c|}
\hline \multirow[b]{2}{*}{ No } & \multirow[b]{2}{*}{$\begin{array}{l}\text { Gol. } \\
\text { Tarif }\end{array}$} & \multirow[b]{2}{*}{$\begin{array}{l}\text { Batas } \\
\text { Daya }\end{array}$} & \multicolumn{2}{|r|}{ Reguler } & \multirow{2}{*}{$\begin{array}{c}\text { Pra } \\
\text { Bayar } \\
\text { (Rp/ } \\
\text { kWh) }\end{array}$} \\
\hline & & & $\begin{array}{c}\text { Biaya Beban } \\
\text { (Rp/kVA/ } \\
\text { bulan) }\end{array}$ & $\begin{array}{l}\text { Biaya Pemakaian } \\
\text { (Rp/kWh) }\end{array}$ & \\
\hline \multirow{3}{*}{1} & \multirow{3}{*}{$\begin{array}{l}\text { R-1/ } \\
\text { TR }\end{array}$} & \multirow{3}{*}{ s.d. $450 \mathrm{VA}$} & \multirow{3}{*}{11.000} & Blok I : 0 s.d. $30 \mathrm{kWh}: 169$ & \multirow{3}{*}{415} \\
\hline & & & & $\begin{array}{l}\text { Blok II : di atas } 30 \mathrm{kWh} \\
\text { s.d. } 60 \mathrm{kWh}: 360 \\
\end{array}$ & \\
\hline & & & & $\begin{array}{l}\text { Blok III : di atas } 60 \mathrm{kWh} \text { : } \\
495\end{array}$ & \\
\hline \multirow[t]{3}{*}{2} & $\begin{array}{l}\mathrm{R}-1 / \\
\mathrm{TR}\end{array}$ & $900 \mathrm{VA}$ & 20.000 & Blok I : 0 s.d. $20 \mathrm{kWh}$ : 275 & \multirow{3}{*}{605} \\
\hline & & & & $\begin{array}{l}\text { Blok II : di atas } 20 \mathrm{kWh} \\
\text { s.d. } 60 \mathrm{kWh}: 445\end{array}$ & \\
\hline & & & & $\begin{array}{l}\text { Blok III : di atas } 60 \mathrm{kWh} \text { : } \\
495\end{array}$ & \\
\hline 3 & $\begin{array}{l}\mathrm{R}-1 / \\
\mathrm{TR}\end{array}$ & $1.300 \mathrm{VA}$ & $\left.{ }^{*}\right)$ & 1.352 & 1.352 \\
\hline 4 & $\begin{array}{l}\mathrm{R}-1 / \\
\mathrm{TR}\end{array}$ & $2.200 \mathrm{VA}$ & $\left.{ }^{*}\right)$ & 1.352 & 1.352 \\
\hline 5 & $\begin{array}{l}\mathrm{R}-2 / \\
\mathrm{TR}\end{array}$ & $\begin{array}{l}\text { 3.500 s.d. } \\
5.500 \mathrm{VA}\end{array}$ & $\left.{ }^{*}\right)$ & 1.352 & 1.352 \\
\hline 6 & $\begin{array}{l}\mathrm{R}-3 / \\
\mathrm{TR}\end{array}$ & $\begin{array}{l}6.600 \mathrm{VA} \\
\text { ke atas }\end{array}$ & $\left.{ }^{*}\right)$ & 1.352 & 1.352 \\
\hline
\end{tabular}

\section{Catatan:}

*) diterapkan rekening minimum (RM):

RM1 = 40 (Jam Nyala) X Daya Tersambung (kVA) x Biaya Pemakaian

$9 \quad$ Peraturan Menteri ESDM Nomor 31 Tahun 2014 tentang Tarif Tenaga Listrik yang Disediakan oleh Perusahaan Perseroan (Persero) PT. Perusahaan Listrik Negara. 
Dalam hal ini harga persatuan listrik yang digunakan tergantung pada kuantitas output yang dikonsumsi oleh konsumen. Fenomena ini seringkali disebut dengan block pricing. Pada kasus ini pemakai komoditas A dalam kuantitas yang semakin banyak akan memperoleh harga yang sama atau mendekati marginal cost.

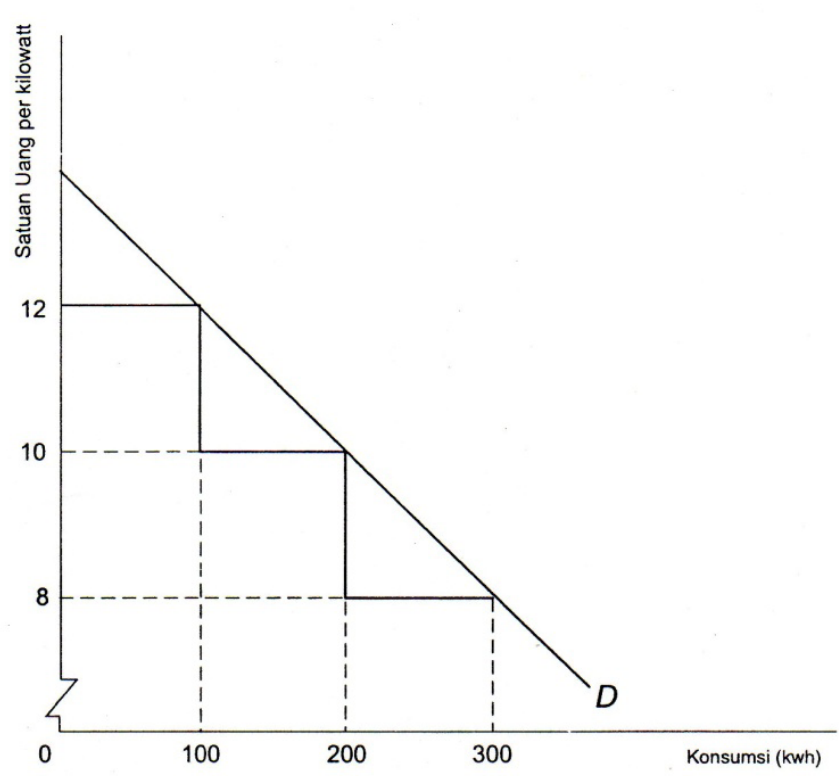

Gambar 2

Diskriminasi Harga Derajat Kedua

Sebagaimana dengan kebijakan harga sebelumnya block pricing dapat meningkatkan keuntungan perusahaan dengan mengambil bagian dari surplus konsumen dengan bertambahnya pemakaian produk. Meskipun demikian harga derajat kedua ini tidak dapat mengambil semua surplus konsumen menjadi keuntungan pengusaha monopoli sebagaimana yang dapat dilakukan pada kebijakan diskriminasi harga derajat pertama.

\section{Diskriminasi Harga Derajat Ketiga}

Monopolis yang ingin menjalankan kebijakan diskriminasi harga, harus menetapkan harga di tiap-tiap pasar agar keuntungan dapat dimaksimumkan. Dalam hal ini monopolis harus mempertimbangkan biaya produksi dan sifat permintaan di tiap-tiap pasar. Misalkan, kurva average cost (AC) dan marginal cost (MC) perusahaan monopolis adalah seperti digambarkan dalam Gambar 3 (iii). Misalkan pula produksi perusahaan monopoli tersebut dijual di dua pasar, yaitu di pasar dalam negeri, dengan kurva permintaan $\left(D_{d}\right)$ dan marginal revenue $\left(\mathrm{MR}_{\mathrm{d}}\right)$ sebagaimana ditunjukkan dalam gambar 3 (i) dan di pasar luar negeri dengan kurva permintaan (Dw) dan marginal revenue (MRw) sebagaimana ditunjukkan dalam gambar 3 (ii). Gabungan permintaan kedua pasar tersebut ditunjukkan oada gambar 3 (iii), yaitu kurva $\mathrm{D}_{\mathrm{d}+\mathrm{w}}$. Begitu juga kurva $\mathrm{MR}_{\mathrm{d}+\mathrm{w}}$ adalah kurva marginal revenue bila analisis terhadap hasil penjualan di kedua pasar tersebut digabungkan. 


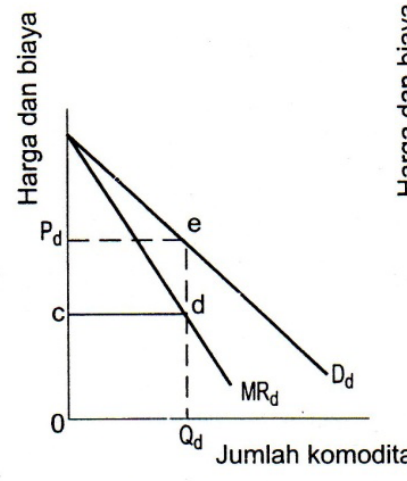

(i) Pasar dalam negeri

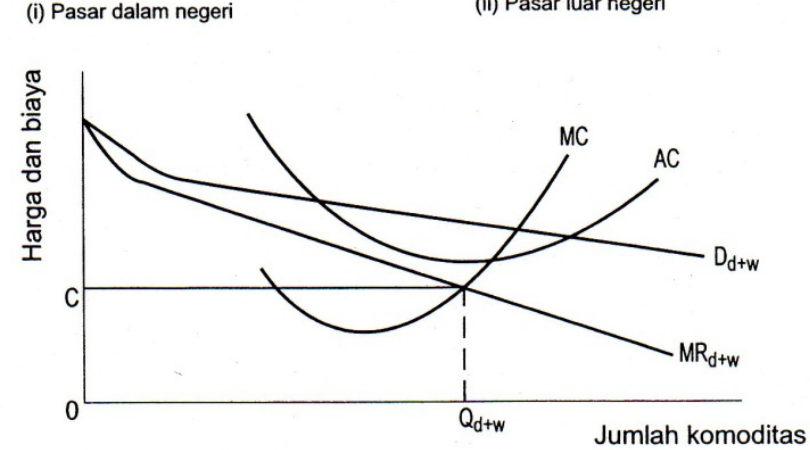

(iii) Keseimbangan Monopoli

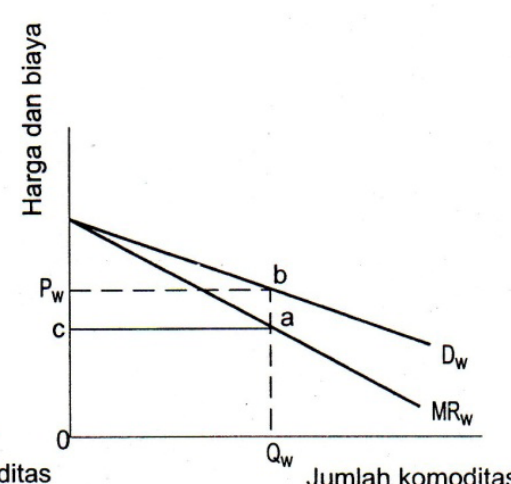

(ii) Pasar luar negeri

\section{Gambar 3}

\section{Diskriminasi Harga Derajat Ketiga}

Perusahaan monopoli akan memperoleh keuntungan maksimum bila $\mathrm{MR}_{\mathrm{d}+\mathrm{w}}=\mathrm{MC}$, keadaan tersebut dicapai bila monopolis memproduksi sebagai $\mathrm{Q}_{\mathrm{d}+\mathrm{w}}$. Saat perusahaan memproduksi $\mathrm{Q}_{\mathrm{d}+\mathrm{w}}$ marginal costnya adalah OC. Agar di tiap pasar diperoleh keuntungan maksimum (dan selanjutnyamemaksimumkankeseluruhan keuntungan perusahaan), maka penjualan di tiap-tiap pasar harus memenuhi syarat marginal cost OC sama dengan marginal revenue di masing-masing pasar. Dengan demikian pemaksimuman keuntungan di pasar dalam negeri tercapai saat $\mathrm{OC}=$ $\mathrm{MR}_{\mathrm{d}}$ dan di pasar luar negeri tercapai saat $\mathrm{OC}=\mathrm{MR}_{\mathrm{w}}$. Dengan demikian, keuntungan maksimum di kedua pasar akan dicapai bila di pasar dalam negeri dijual output sebanyak $Q_{d}$ dan di pasar luar negeri dijual output sebanyak $\mathrm{Q}_{w^{*}}$. Harga pasar di dalam negeri dalam $\mathrm{P}_{\mathrm{d}}$ dan harga di pasar luar negeri adalah $\mathrm{P}_{\text {w' }}$ Jumlah keuntungan yang diperoleh perusahaan tersebut adalah $\mathrm{CdeP}_{d}$ (di pasar dalam negeri) ditambah $\mathrm{CabP}_{\mathrm{w}}$ (di pasar luar negeri).

Dalam diskriminasi harga derajat ketiga monopolis menjual komoditasnya di pasar yang memiliki elastisitas permintaan yang berbeda-beda. Dimisalkan produsen menjual barang di dua pasar yang berbeda yaitu di pasar A dan di pasar B. Pertamatama harus dipahami, bahwa produsen akan mendapatkan total revenue yang maksimal bila marginal revenue di pasar $\mathrm{A}\left(\mathrm{MR}_{\mathrm{A}}\right)$ sama dengan marginal revenue di pasar yang lain $\left(\mathrm{MR}_{\mathrm{B}}\right)$. Ini menunjukkan jumlah komoditas $\mathrm{Q}$ yang dialokasikan di pasar A sebanyak $Q_{A}$ dan di pasar $B$ sebanyak $\mathrm{Q}_{\mathrm{B}}$. Harga di pasar $\mathrm{A}$ adalah $\mathrm{P}_{\mathrm{A}}$ dan harga di pasar $\mathrm{B}$ adalah $\mathrm{P}_{\mathrm{B}}$. Karena pasar A menunjukkan permintaan yang lebih inelastis daripada permintaan di pasar B, maka harga di pasar A lebih tinggi dari pada di pasar B. Bila dimisalkan $A=2$ dan $\mathrm{B}=3$, maka akan ditemukan bahwa $\mathrm{P}_{\mathrm{B}}$ $=3 / 4 \mathrm{P}_{\mathrm{A}}$.

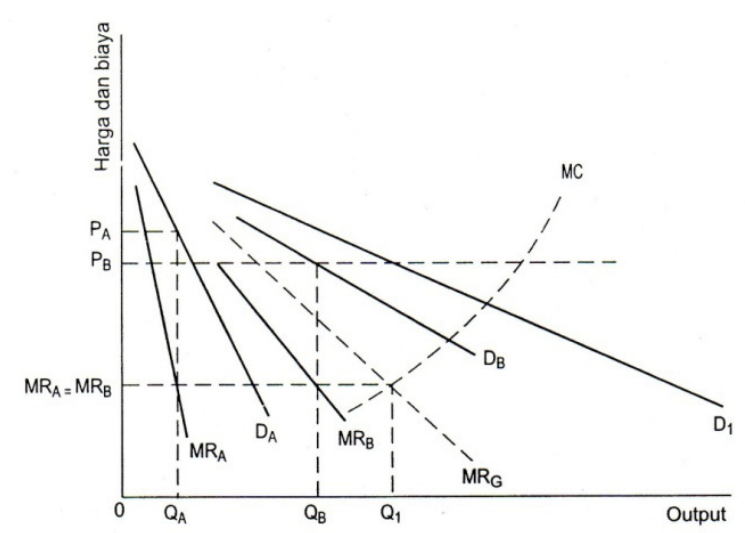

Gambar 4

Elastisitas Permintaan dan Diskriminasi Harga 
Biaya produksi untuk menghasilkan komoditas X tetap ditunjukkan oleh kurva AC dan kurva MC. Sehingga untuk menentukan keuntungan yang diperoleh di masing-masing pasar, kita harus mengurangkan biaya rata-rata itu dari tingkat harga di masing-masing pasar dan kemudian mengalikannya dengan jumlah yang dijual di masing-masing pasar tersebut. Dengan menjumlahkan keuntungan total di pasar A dan pasar B kita akan mendapatkan jumlah keuntungan dari monopolis yang bekerja dengan diskriminasi harga derajat ketiga tersebut.

Yang menjadi persoalan adalah penentuan jumlah komoditas yang dihasilkan, alokasi produk serta harga dimasing-masing pasar tersebut. Dengan diketahuinya pula kurva permintaan di pasar A dan di pasar B, maka diketahui pula kurva marginal revenue di masingmasing pasar tersebut. Masing-masing kurva itu ada $\mathrm{D}_{\mathrm{A}^{\prime}}$ DB dan $\mathrm{MR}_{\mathrm{A}}$ dan $\mathrm{MR}_{\mathrm{B}}$. Untuk menentukan jumlah komoditas yang dihasilkan, mula-mula kurva penerimaan masing-masing pasar $\mathrm{MR}_{\mathrm{A}}$ dan $\mathrm{MR}_{\mathrm{B}}$ harus dijumlahkan secara horisontal sehingga didapat kurva penerimaan gabungan $\left(\mathrm{MR}_{\mathrm{G}}\right)$. Produksi ditentukan oleh perpotongan kurva penerimaan gabungan $\mathrm{MR}_{\mathrm{G}}$ itu dengan kurva marginal cost $\mathrm{MC}$ dan menghasilkan produksi total $Q_{t}$. Dengan menarik garis horisontal dari titik perpotongan kurva penerimaan gabungan dan biaya marjinal ke kiri, akan dapat ditentukan jumlah produk yang harus dialokasikan di pasar A dan di pasar B pada perpotongan antara garis horisontal itu dengan kurva penerimaan marjinal masing-masing pasar MRA untuk pasar A dan MRB untuk pasar B dan menghasilkan komoditas OQA untuk pasar A dan OQB untuk pasar B. Harga komoditas di masingmasing pasar adalah PA di pasar A dan PB di pasar B. Masing-masing harga itu ditentukan dengan menarik garis vertikal padajumlah outputOQA sampai memotong kurva permintaan DA dan dari output ORB di pasar B sampai memotong kurva permintaan DB. Tampak pada gambar 4 bahwa di pasar yang permintaannya lebih elastis (yaitu pasar B) tingkat harga komoditas PB lebih rendah daripada di pasar A (PA) yang permintaannya lebih tidak elastis (inelastis). Perhatikan pula bahwa $Q_{A}+Q_{B}=Q_{t}$.

\section{Perspektif Undang-Undang No. 5 Tahun 1999 tentang Larangan Praktek Monopoli dan Persaingan Usaha Tidak Sehat Terhadap Diskriminasi Harga}

Di dalam Undang-Undang Nomor 5 Tahun 1999, diskriminasi yang berkaitan dengan harga diatur dalam dua kelompok aturan atau pasal, yakni diskriminasi harga yang disepakati di bawah payung perjanjian dan diskriminasi yang dilakukan secara sepihak atau tanpa perjanjian.

\section{a. Diskriminasi harga yang disepakati di bawah payung perjanjian.}

Diskriminasi harga yang disepakati di bawah payung perjanjian diatur dalam Pasal 5 ayat 1 dan Pasal 6 Undang-Undang Nomor 5 Tahun 1999 tentang Larangan Praktek Monopoli dan Persaingan Usaha Tidak Sehat.

Pasal 6 menyatakan:

"Pelaku usaha dilarang membuat perjanjian yang mengakibatkan pembeli yang satu harus membayar 
dengan harga yang berbeda dari harga

yang harus dibayar oleh pembeli lain untuk barang dan atau jasa yang sama".

Pasal ini membahas mengenai perjanjian diskriminasi harga (price discrimination agreement) yakni, perjanjian yang dibuat oleh pelaku usaha dengan pelaku usaha lainnya dimana untuk suatu produk yang sama dijual kepada setiap konsumen dengan harga yang berbeda-beda.

Konsep larangan dalam Pasal 6 Undang-Undang Nomor 5 Tahun 1999 mensyaratkan adanya suatu perjanjian yang dibuat oleh pelaku usaha yang isinya mengakibatkan pembeli yang satu harus membayar berbeda dengan pembeli lainnya untuk barang atau jasa yang sama. Pengertian perjanjian maupun pelaku usaha di sini sesuai dengan pengertian dalam ketentuan Pasal 1 Undang-Undang Nomor 5 Tahun 1999.

Berdasarkan ketentuan Pasal 6 tersebut, diskriminasi harga dilarang apabila pelaku usaha membuat suatu perjanjian dengan pelaku usaha lain yang mengakibatkan pembeli satu harus membayar harga yang tidak sama atau berbeda dengan harga yang harus dibayar oleh pembeli lain untuk barang dan/ atau jasa yang sama, karena hal ini dapat menimbulkan persaingan usaha yang tidak sehat di kalangan pelaku usaha atau dapat merusak persaingan usaha. Dalam hal ini menurut Rachmadi Usman terdapat tiga jenis dan tingkatan strategis diskriminasi harga, di mana setiap tingkatan menuntut informasi yang berbeda mengenai konsumen, yaitu: ${ }^{10}$

1) Diskriminasi harga sempurna, dimana produsen akan menetapkan harga yang berbeda untuk setiap konsumen. Dengan menetapkan strategi ini, produsen akan menyerap seluruh surplus konsumen, sehingga dapat mencapai laba yang paling tinggi.

2) Pada situasi dimana produsen tidak dapat mengidentifikasi maksimum harga yang dapat dikenakan untuk setiap konsumen, atau situasi dimana produsen tidak dapat melanjutkan struktur harga yang sama untuk tambahan unit penjualan, maka produsen dapat menetapkan strategi diskriminasi tingkat harga kedua, dimana produsen akan menerapkan sebagian dari surplus konsumen. Pembeli yang bersedia membeli barang lebih banyak diberikan harga per unit yang lebih murah. Strategi ini banyak dilakukan pada penjualan grosir atau pasar swalayan besar.

3) Bentuk terakhir diskriminasi harga umumnya diterapkan produsen yang mengetahui bahwa permintaan atas produk mereka beragam secara sistematik berdasarkan karakteristik konsumen dan kelompok demografis. Interpretasi dari rumusan:"...pembeli harus membayar dengan harga yang berbeda...", jika ini yang menjadi landasan penafsirannya, maka pembeli harus membayar dengan harga yang berbeda tidak hanya disebabkan oleh perjanjian dalam hubungan vertikal, tetapi juga

10 Rachmadi Usman, Hukum Persaingan Usaha Di Indonesia, Cet. 1, PT. Gramedia Pustaka Utama, Jakarta, 2004, hlm. 49-50. 
dimungkinkan oleh perjanjian dalam hubungan horizontal. Contoh, perjanjian ekslusif antara perusahaan kartu kredit $\mathrm{X}$ dengan jasa angkutan penerbangan udara Y dalam hubungan horizontal menyebabkan diskriminasi harga bagi pemegang kartu kredit non X. Meskipun demikian, pemeriksaan terhadap contoh kasus terakhir hendaknya tidak dilakukan dengan menggunakan Pasal 6, melainkan dengan Pasal 5 ayat 1.

Pasal 5 ayat 1 dengan formulasi sebagai berikut:

"Pelaku usaha dilarang membuat perjanjian dengan pelaku usaha pesaingnya untuk menetapkan harga atas suatu barang dan atau jasa yang harus dibayar oleh konsumen atau pelanggan pada pasar bersangkutan yang sama".

Pasal 5 ayat 1 pada dasarnya merupakan larangan terhadap setiap perjanjian harga yang bersifat horizontal. Salah satu jenis perjanjian harga horizontal adalah perjanjian harga untuk memperlakukan pembeli tertentu berbeda dalam hal harga dengan pembeli atau pelanggan lainnya.

Berdasarkan ketentuan Pasal 5 ayat (1) Undang-Undang Nomor 5 Tahun 1999, pelaku usaha dilarang mengadakan perjanjian dengan pelaku usaha pesaingnya guna menetapkan suatu harga tertentu atas suatu barang dan/atau jasa yang akan diperdagangkan pada pasar bersangkutan. Larangan muncul, sebab perjanjian seperti itu akan meniadakan persaingan usaha diantara pelaku usaha yang mengadakan perjanjian tersebut. Dalam Pasal 5 ayat (1) dikatakan bahwa perjanjian penetapan harga dilarang tanpa melihat efek negatif dari perjanjian tersebut terhadap persaingan. Dengan kata lain, walaupun efek negatif terhadap persaingan usaha kecil. Perjanjian price fixing tetap dilarang.

Akan tetapi undang-undang memberikan pengecualian terhadap larangan membuat perjanjian tentang penetapan harga antar pelaku usaha ini, yaitu jika perjanjian penetapan harga tersebut dibuat:

1) Dalam suatu usaha patungan (joint ventures); atau

2) Didasarkan pada undang-undang yang berlaku (vide Pasal 5 ayat (2) UndangUndang Nomor 5 Tahun 1999).

Dalam undang-undang ini tidak dijelaskan usaha patungan sepertiapa yang bisa dikecualikan. Bila usaha patungan membuat collateral restraint, yakni perjanjian yang membatasi kompetisi dimasa datang antara para pihak, usaha ini bisa menghadapi tuntutan pelanggaran peraturan di bidang anti monopoli dan persaingan usaha tidak sehat. Dengan demikian tidak bisa dikatakan bahwa semua perjanjian dalam usaha patungan tidak akan merugikan persaingan. Perlu dibuatkan penjelasan lagi mengenai kriteria usaha patungan yang dapat dikecualikan.

\section{b. Diskriminasi harga tanpa perjanjian}

Pasal 19 Undang-Undang No. 5 Tahun 1999 dengan judulnya "Penguasan Pasar" menyatakan bahwa pelaku usaha dilarang melakukan satu atau beberapa kegiatan, baik sendiri maupun bersama pelaku usaha lain, yang dapat mengakibatkan terjadinya praktik monopoli dan atau persaingan usaha tidak sehat berupa: 
1) menolak dan atau menghalangi pelaku usaha tertentu untuk melakukan kegiatan usaha yang sama pada pasar bersangkutan; atau

2) menghalangi konsumen atau pelanggan pelaku usaha pesaingnya untuk tidak melakukan hubungan usaha dengan pelaku usaha pesaingnya itu; atau

3) membatasi peredaran dan atau penjualan barang dan atau jasa pada pasar bersangkutan; atau

4) melakukan praktik diskriminasi terhadap pelaku usaha tertentu.

Pasal 19 Undang-Undang Nomor 5 Tahun 1999 ini mengesankan ditujukan kepada para pelaku usaha yang harus mempunyai kemampuan untuk mempengaruhipasarsehingga mempunyai kekuatan pasar yang substansial. Hal tersebut mungkin didasarkan kepada anggapan bahwa perbuatan yang dimuat pada huruf a sampai d hanya dapat terjadi jika pelaku usaha memiliki posisi pasar yang kuat. Namun, yang menjadi pertimbangan bukanlah persoalan pangsa pasar saja, melainkan dapat langsung diterapkan kepada pelaku usaha yang melakukan kegiatan usahanya, baik secara sendiri-sendiri atau bersama-sama dengan pelaku usaha yang lain. ${ }^{11}$ Dengan kata lain, penerapan Pasal 19 tidak tergantung pada dilewati atau tidak dilewatinya batas pangsa pasar tertentu. ${ }^{12}$

Terminologi diskriminasi dalam Industrial Organization biasanya lebih banyak digunakan untuk konteks pembedaan harga untuk produk yang sama dengan alasan yang tidak terkait dengan perbedaan biaya produksi. ${ }^{13}$ Dalam hal ini dikenal diskriminasi harga dengan berbagai derajatnya. Diskriminasi harga derajat satu jika penjual mampu menetapkan harga yang berbeda-beda untuk konsumen yang berbeda sehingga dapat meraup seluruh surplus konsumen. Diskriminasi harga derajat dua berlaku dalam bentuk pemberlakuan harga yang berbeda untuk blok penggunaan yang berbeda sehingga sebagian, tetapi tidak semuanya, surplus konsumen dapat diambil oleh penjual. Diskriminasi derajat tiga memberlakukan harga yang berbeda untuk barang yang sama pada pasar yang berbeda elastisitasnya. ${ }^{14}$

Syarat untuk dapat menerapkan strategi diskriminasi harga adalah adanya market power yang dimiliki oleh perusahaan atau penjual yang pada umumnya dimiliki oleh perusahaan monopoli. Syarat kedua, perusahaan harus mampu mencegah penjualan kembali barang yang dibeli pada harga yang lebih murah ke pasar dengan harga yang lebih mahal. Oleh karena itu strategi ini pada

\footnotetext{
11 Knud Hansen, et al., Undang-undang Larangan Praktik Monopoli dan Persaingan Usaha Tidak Sehat: Law Concerning Prohibition of Monopolistic Practices and Unfair Business Competition. GTZ dan Katalis Publishing Media Services, Jakarta, 2002, hlm. 289.

12 Ibid., hlm. 291.

13 Peraturan Komisi Pengawas Persaingan Usaha Nomor 3 Tahun 2011 tentang Pedoman Pasal 10 Huruf d (Praktek Diskriminasi) Undang-Undang Nomor 5 Tahun 1999 tentang Larangan Praktek Monopoli Dan Persaingan Usaha Tidak Sehat, hlm. 2.

14 Ibid.
} 
umumnya efektif untuk pasar jasa dan pasar yang terpisah cukup jauh secara geografis. ${ }^{15}$

Karena diskriminasi harga hanya mampu dilakukan oleh perusahaan yang mempunyai market power, maka strategi ini juga berpotensi untuk disalahgunakan untuk melakukan berbagai hal yang dilarang pada Undang-Undang No. 5 Tahun 1999. Dengan kemampuan diskriminasi harga, produsen atau penjual dapat menurunkan harga pada suatu pasar tertentu untuk menyingkirkan pesaingnya dari pasar tersebut atau menghambat perusahaan baru untuk masuk tanpa khawatir mengalami kerugian karena akan dikompensasi oleh penerimaan dan keuntungan dari pasar lain yang dikenakan harga yang lebih tinggi. ${ }^{16}$

Jika dilihat dari aspek distribusi, jelas diskriminasi akan meningkatkan penerimaan atau keuntungan produsen atau penjual dengan berkurangnya kesejahteraan konsumen karena seluruh atau sebagian surplus mereka diambil. Namun demikian, diskriminasi harga jual dapat berdampak positif terhadap kesejahteraan masyarakat secara keseluruhan dibandingkan dengan pemberlakuan satu harga (non diskriminasi). Dengan diskriminasi harga, jumlah barang yang dihasilkan dan dapat dinikmati masyarakat akan meningkat dibandingkan dengan metode satu harga yang biasanya diterapkan oleh perusahaan monopoli. Secara teoritis hal ini menyebabkan berkurangnya deadweight social loss yang terjadi akibat struktur pasar yang monopolistis. ${ }^{17}$ Oleh karena itu, apakah praktek diskriminasi harga pada akhirnya menguntungkan atau merugikan bagi masyarakat merupakan masalah empiris yang harus dikaji kasus per kasus.

Selain diskriminasi harga dengan memberlakukan harga yang berbeda untuk segmen pasar yang berbeda elastisitasnya di atas, bentuk lain diskriminasi harga juga dapat ditemukan dalam bentuk perbedaan harga intemporal (misal: harga berbeda pada waktu yang berbeda seperti harga komputer yang sama berbeda pada saat baru diluncurkan dengan harga setelah beberapa waktu), peak load (misal: harga tiket pesawat atau hotel berbeda pada saat liburan panjang dengan bukan liburan), two part tariff (misal: pemain golf dikarenakan iuran angggota yang tetap, lalu dikenakan biaya terpisah untuk setiap penggunaan sehingga anggota yang menggunakan lapangan golf tersebut lebih sering akan mendapatkan harga rata-rata yang lebih rendah dibandingkan dengan anggota yang jarang menggunakannya), bundling dimana suatu barang yang dijual secara paket dengan barang lainnya sementara tersedia barang yang sama dapat dibeli tanpa paket dengan harga yang sama, dan tying dimana seorang konsumen disyaratkan membeli barang tertentu sebelum dapat membeli suatu barang. ${ }^{18}$

Selain diskriminasi harga juga terdapat diskriminasi non harga. Dalam

\begin{tabular}{ll}
\hline 15 & Ibid. \\
16 & Ibid., hlm. 3. \\
17 & Ibid. \\
18 & Ibid.
\end{tabular}


hal ini, diskriminasi non harga adalah yang sebagaimana diatur dalam Pasal 19 huruf d, yang dimaksudkan sebagai tindakan atau perlakuan dalam berbagai bentuk yang berbeda, yang dilakukan oleh seorang pelaku usaha terhadap pelaku usaha tertentu. ${ }^{19}$ Diskriminasi dapat didasarkan pada alasan yang tidak wajar seperti SARA, maupun alasan lain karena kepentingan tertentu seperti keuntungan pribadi atau teknis.

Bentuk diskriminasi non harga yang sangat jelas adalah penunjukkan langsung sementara terdapat lebih dari satu perusahaan yang mampu melakukan hal yang sama. ${ }^{20}$ Diskriminasi non harga juga terjadijikakesempatanberkompetisihanya diberikan kepada beberapa perusahaan, sementara sebagian perusahaan lain yang juga mampu tidak diberi peluang. Sebagaimana halnya dengan diskriminasi harga, diskriminasi non harga juga pada umumnya memerlukan adanya penguasaan pasar (market control) dari pelaku usaha tertentu. ${ }^{21}$ Namun dalam kasus tertentu, penguasaan pasar dalam arti pangsa pasar tidak harus besar tetapi bagi mitra usaha merupakan pasar yang signifikan. Lebih lanjut, diskriminasi nonharga juga diperkirakan paling terhadap masalah persaingan usaha karena sudah jelas ada perusahaan pesaing yang dirugikan akibat tindakan diskriminatif tersebut. Namun demikian perlu dilihat motif dan dampaknya untuk memutuskan apakah praktik tersebut dapat diterima atau tidak. Beberapa perusahaan lainnya misalnya memberlakukan diskriminasi untuk mengembangkan pengusaha lokal, mengembangkan UKM dan diskriminasidiskriminasi lain yang bernuansa positif. Untuk memastikan bahwa alasan-alasan tersebut tidak hanya digunakan sebagai kamuflase untuk tindakan koruptif dan kepentingan pribadi, diperlukan investigasi lebih jauh.

Dari sudut pandang ekonomi, kegiatan penguasaan pasar diartikan sebagai kemampuan pelaku usaha dalam mempengaruhi pembentukan harga, atau kuantitas produksi atau aspek lainnya dalam sebuah pasar. Aspeklainnya tersebut dapat berupa, namun tidak terbatas pada pemasaran, pembelian, distribusi, penggunaan, atau akses atas barang atau jasa tertentu di pasar bersangkutan. ${ }^{22}$ Kegiatan ini dapat dilakukan sendiri oleh satu pelaku usaha atau secara bersamasama dengan pelaku usaha lainnya, dan dapat terdiri dari satu atau beberapa kegiatan sekaligus.

Kegiatan penguasaan pasar sangat erat kaitannya dengan pemilikan posisi dominan dan kekuatan pasar yang signifikan di pasar bersangkutan. Penguasaan pasar akan sulit dicapai apabila pelaku usaha, baik secara sendiri maupun bersama-sama, tidak memiliki kedudukan yang kuat di pasar bersangkutan. Selain didukung oleh pemilikan posisi dominan, dan atau memiliki kekuatan pasar yang signifikan, penguasaan pasar oleh pelaku usaha juga bisa terjadi melalui pemilikan faktor-faktor khusus yang tidak dimiliki

\begin{tabular}{ll}
\hline 19 & Ibid., hlm. 4. \\
20 & Ibid. \\
21 & Ibid. \\
22 & Ibid., hlm. 5.
\end{tabular}


oleh pesaingnya. ${ }^{23}$ Faktor-faktor khusus ini dapat berupa, namun tidak terbatas pada HAKI, regulasi pemerintah, hal ekslusif (lisensi), jaringan distribusi, dukungan finansial, fasilitas penting, loyalitas atau preferensi konsumen. Pemilikan atas satu atau lebih faktor-faktor ini membuat pelaku usaha berada pada posisi yang lebih diuntungkan dibandingkan para pesaingnya.

Kegiatan melakukan praktik diskriminasi terhadap pelaku usaha tertentu merupakan penentukan perlakuan dengan cara yang berbeda mengenai persyaratan pemasokan atau persyaratan pembelian barang dan/ atau jasa. Segala macam perlakuan yang berbeda terhadap pelaku usaha tertentu dapat termasuk dalam cakupan Pasal 19 huruf d ini. Kemudian, yang membedakan antara Pasal 6 dan Pasal 19 huruf d adalah bahwa diskriminasi yang dimaksud dalam Pasal 6 adalah diskriminasi dalam bentuk harga kepada pembeli yang dilakukan dalam bentuk perjanjian, sedangkan diskriminasi dalam Pasal 19 huruf d dilakukan tidak hanya dalam bentuk harga tetapi juga dalam bentuk lainnya yang tidak harus dilakukan dalam bentuk perjanjian.

Melakukan praktik diskriminasi artinya termasuk menolak sama sekali melakukan hubungan usaha, menolak melakukan sama sekali hubungan usaha, menolak syarat-syarat tertentu atau perbuatan lain, dimana pelaku usaha lain diperlakukan dengan cara yang tidak sama. Bentuk perilaku diskriminasi tidak terhitung, dan usaha untuk menentukan bahwa suatu kegiatan diskriminasi cukup beralasan atau tidak tergantung kepada setiap kasus, sehingga peran yurisprudensi menjadi penting. ${ }^{24}$ Namun, bagian yang paling penting dalam menentukan suatu perbuatan diskriminasi berasalan atau tidak, diperlukan analisis pengimbangan antara kepentingan pelaku usaha yang melakukan diskriminasi dan pelaku usaha yang mengalami diskriminasi. Dengan demikian maka penentuan harga yang berbeda-beda (antara lain potongan harga menurut kuantitas) tidak otomatis dilarang karena bisa saja potongan harga dilakukan akibat berkurangnya biaya transaksi atau sebagai respon terhadap persaingan. ${ }^{25}$

Perilaku diskriminatif dapat juga dilakukan oleh pemasok barang bermerek kepada penyalurnya dengan alasan untuk mempertahankan reputasi, kualitas, atau harga. Selain itu, diskriminasi juga bisa dilakukan terhadap pelaku usaha yang telah menjadi mitra tetap dan yang tidak dengan mengubah sistem penjualan dari yang menggunakan penyalur menjadi penjualan langsung ke konsumen akhir. Dalam kasus ini, perjanjian dengan penyalur suatu barang yang tergantung pada produsen hanya dapat dibatalkan jika masa berlakunya sudah cukup lama sehingga penyalur yang bersangkutan berkesempatan untuk mencari kontrak penjualan lain. ${ }^{26}$

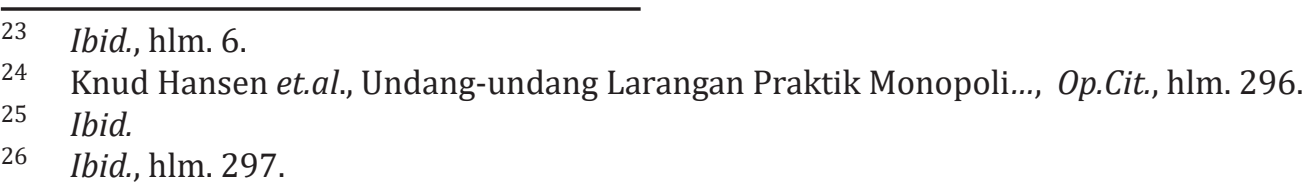


Pasal 19 huruf d tidak hanya berlaku untuk pemasok (supplier) yang menjual barang/jasa saja, tetapi juga kepada pelaku usaha yang membelinya. Kondisi ini terjadi ketika pemasok barang atau jasa tergantung kepada pelanggannya apabila pelanggan tersebut memiliki posisi dominan atau tidak tersedia alternatif yang cukup dan pantas bagi pemasok untuk menjual barang/jasa kepada pelanggan lain. ${ }^{27}$ Jika pelaku usaha memiliki posisi yang kuat dalam pasar menyalahgunakan posisinya tersebut untuk mendorong pelaku usaha lain dalam rangka hubungan usaha agar memberikan syarat istimewa tanpa adanya alasan yang meyakinkan, maka perilaku yang seperti itu pada umumnya disebut sebagai "diskriminasi pasif". Perilaku seperti itu baru dapat dianggap menghambat persaingan jika pembeli tidak memberikan perlakuan yang sama terhadap semua calon pemasok dalam rangka memperoleh persyaratan pembelian yang paling menguntungkan, melainkan melakukan pembedaan secara sistematik. ${ }^{28}$ Namun, apabila pembedaan dilakukan hanya mencakup potongan harga yang melambangkan persaingan harga dan kualitas, maka alasan tersebut secara materil dianggap meyakinkan sehingga tidak dapat dianggap sebagai perilaku diskriminatif.

Secara ringkas contoh hipotesa dari praktik diskriminasi yang melanggar Pasal 19 huruf d antara lain:

1) Penunjukan langsung dalam suatu pekerjaan;
PT X melakukan penunjukan langsung kepada PT Y tanpa melalui proses tender guna melakukan pengembangan sistem e-reporting dan monitoring yang disertai pemberian hak eksklusif sebagai satu-satunya penyelenggara sistem e-reporting dan monitoring di tempat PT $\mathrm{X}$ dan memungut biaya aplikasinya kepada perusahaan yang menggunakannya. Kebijakan PT X tersebut dianggap telah mendiskriminasi pelaku usaha jasa penyelenggara sistem e-reporting lainnya dengan memperlakukan PT Y secara istimewa. Contoh kasus ini melanggar Pasal 19 huruf d.

2) Menolak melakukan hubungan usaha dengan pihak tertentu tanpa justifikasi hukum, sosial, ekonomi, teknis, dan alasan lainnya yang dapat diterima.

PT A merupakan produsen tepung terbesar dan terbaik di Indonesia. Pada saat ini sudah terdapat beberapa pabrik tepung selain PT A dan juga terdapat banyak impor terigu dari Turki. PT D sebagai produsen roti premium ingin mendapatkan terigu kualitas paling baik yang diproduksi PT A, namun ketika mengajukan permintaan pembelian ditolak tanpa alasan yang jelas, padahal kapasitas produksi PT A mempu memenuhi permintaan tersebut. Pada dasarnya PT A memiliki banyak pesaing, tetapi produsen tepung menganggap bahwa kualitas tepung produksi PT A merupakan yang terbaik di kelasnya sehingga membutuhkan bahan tersebut. Tetapi PT A menolak menjual dan lebih memilih menjual kepada afiliasinya. 
3) Menetapkan persyaratan tertentu yang mengarah kepada perusahaan tertentu tanpa justifikasi hukum, sosial, ekonomi, teknis, dan alasan lainnya yang dapat diterima.

PT. B memiliki produk obat dengan zat amlodipine untuk penyakit darah tinggi yang sangat laku di pasaran sehingga banyak distributor yang ingin turut memasarkan obat tersebut. Akan tetapi untuk menjadi distributor PT B, PT B mensyaratkan kepemilikan modal dan alat tertentu yang hanya dapat dipenuhi oleh PT C yang merupakan afiliasinya, meskipun sebenarnya persyaratan tersebut tidak diperlukan untuk distribusi obat dimaksud. Perusahaan lain yang memiliki cakupan di Jawa, Bali dan Sumatera serta memiliki kemampuan melakukan distribusi minimal untuk wilayah yang sudah menjadi pasarnya selama ini merasa tidak diberikan kesempatan untuk ikut mendistribusikan produk yang laku di pasaran tersebut.

4) Menetapkan syarat yang berbeda untuk pelaku usaha yang berbeda dalam pasar yang sama tanpa justifikasi legal, sosial, ekonomi, teknis dan alasan lannya yang dapat diterima. PT. A adalah hipermarket yang menerima pasokan barang dari para suppliernya untuk memenuhi kebutuhan tokonya. Untuk memenuhi kebutuhan dairy product, PT. A mensyaratkan kepemilikan lemari pendingin bagi perusahaan $\mathrm{C}$ untuk dipasang di tokonya tapi tidak mensyaratkan hal yang sama kepada perusahaan $\mathrm{B}$, karena perusahaan
$B$ dapat menggunakan lemari pendingin milik PT A.

5) Menetapkan syarat yang sama untuk pelaku usaha yang secara ekonomi berbeda kelas.

PT. C yang merupakan sebuah supermarket menetapkan trading terms dan besaran fee yang sama baik kepada pemasok yang termasuk golongan UKM maupun golongan pemasok besar. Hal ini tentu saja secara relatif akan dirasakan lebih berat bagi pemasok kelompok UKM sehingga dapat diartikan bahwa PT C hanya menghendaki pemasok kelompok pengusaha besar. Dengan demikian, persyaratan yang sama untuk kelas yang berbeda dapat dianggap sebagai persyaratan yang diskriminatif sehingga dapat dikategorikan melanggar Pasal 19 huruf d. ${ }^{29}$

Berdasarkan contoh-contoh hipotesa pelanggaran-pelanggaran di atas, maka dapat disimpulkan bahwa indikasi untuk dapat dilakukannya kegiatan-kegiatan sebagaimana yang diuraikan dalam Pasal 19 huruf d antara lain:

1) Adanya perlakuan istimewa yang dilakukan oleh pelaku usaha terhadap pelaku usaha tertentu, dan/atau

2) Perlakuan istimewa tersebut sama sekalitidakberdasarkan pertimbangan yang beralasan.

\section{PENUTUP}

Berdasarkan permasalahan mengenai perspektif ilmu ekonomi dan UndangUndang Nomor 5 Tahun 1999 tentang Larangan Praktek Monopoli dan

$29 \quad$ Peraturan Komisi Pengawas Persaingan Usaha Nomor 3 Tahun 2011 tentang Pedoman Pasal 10 Huruf d (Praktek Diskriminasi) Undang-undang Nomor 5 Tahun 1999 tentang Larangan Praktek Monopoli Dan Persaingan Usaha Tidak Sehat, hlm. 16-17. 
Persaingan Usaha Tidak Sehat terhadap Diskriminasi Harga, maka kesimpulan yang diperoleh adalah sebagai berikut:

1. Perspektif ilmu ekonomi terhadap diskriminasi harga:

a. Diskriminasi harga bersifat netral

b. Terdapat tiga jenis diskriminasi harga:

1) Diskriminasi harga derajat pertama

2) Diskriminasi harga derajat kedua

3) Diskriminasi harga derajat ketiga

2. Perspektif Undang-Undang Nomor 5 Tahun 1999 Tentang Larangan Praktek Monopoli dan Persaingan Usaha Tidak Sehat Terhadap Diskriminasi Harga:

a. Diskriminasi harga di bawah payung perjanjian, yaitu Pasal 5 ayat (1) dan Pasal 6

b. Diskriminasi harga yang dilakukan secara sepihak atau tanpa perjanjian, yaitu Pasal 19 huruf d.

\section{DAFTAR PUSTAKA}

\section{Buku:}

Agus Maulana, Pengantar Ilmu Ekonomi,

Jilid II, Bina Rupa Aksara, Jakarta, 2000.

Ayudha D. Prayoga, et.al., Persaingan Usaha dan Hukum yang Mengaturnya, Proyek ELIPS, Jakarta, 2000.

D. Carlton dan J. Perloff, Modern Industrial Organization, Addiso-Wesley Longman Inc, New York, 1999.
Dominick Salvatore, Ekonomi Manajerial Dalam Perekonomian Global, Edisi 5, Buku 2, Salemba Empat, Jakarta, 2005.

Gunarto Suhardi, Revitalisasi BUMN, Universitas Atmajaya Yogyakarta, 2007.

Hermansyah, Pokok-Pokok Hukum Persaingan Usaha di Indonesia, Kencana, Jakarta, 2008.

Hikmahanto Juwana, "Sekilas Tentang Hukum Persaingan dan UndangUndang Nomor 5 Tahun 1999", Jurnal Magister Hukum, (September 1999).

Knud Hansen, et al., Undang-undang Larangan Praktik Monopoli dan Persaingan Usaha Tidak Sehat: Law Concerning Prohibition of Monopolistic Practices and Unfair Business Competition. GTZ dan Katalis Publishing Media Services, Jakarta, 2002.

Lemhannas, Ekonomi Pancasila, Lemhannas, Jakarta, 1989.

N. Gregory Mankiw, Euston Quah, Peter Wilson, Pengantar Ekonomi Mikro, Salemba Empat, Jakarta, 2012.

Rachmadi Usman, Hukum Persaingan Usaha Di Indonesia, Cet. 1, PT. Gramedia Pustaka Utama, Jakarta, 2004.

Robert S Pindycle and Daniel L. Rubinfeld, Microeconomic, Prentice Hall International Inc, USA, 1998. 
Sri Mamudji, Metode Penelitian dan Penulisan Hukum, Cet. 1, Badan Penerbit Fakultas Hukum Universitas Indonesia, Jakarta, 2005, hlm. 67.

Sugiarto, Teddy Herlambang, Brastoro, RachmatSudjana, Said Kelana, Ekonomi Mikro Sebuah Kajian Komprehensif, PT. Gramedia Pustaka Utama, Jakarta, 2002.

\section{Peraturan Perundang-undangan:}

Undang-Undang Dasar 1945 Amandemen ke IV.

Undang-Undang Nomor 5 Tahun 1999 tentang Larangan Praktek Monopoli dan Persaingan Usaha Tidak Sehat.

Undang-Undang Nomor 20 Tahun 2002 tentang Ketenagalistrikan

Peraturan Menteri ESDM Nomor 31 Tahun 2014 Tentang Tarif Tenaga Listrik yang Disediakan oleh Perusahaan Perseroan (Persero) PT. Perusahaan Listrik Negara.

Peraturan Komisi Pengawas Persaingan Usaha Nomor 3 Tahun 2011 tentang Pedoman Pasal 10 Huruf d (Praktek Diskriminasi) Undang-Undang Nomor 5 Tahun 1999 tentang Larangan Praktek Monopoli Dan Persaingan Usaha Tidak Sehat.

\section{Lainnya:}

www.pln.co.id

www.kppu.go.id www.esdm.go.id

www.listrikindonesia.com 